\title{
BRAND EXPERIENCE EFFECTS ON CONSUMER SOCIAL MEDIA MARKETING PERCEPTIONS AND BRAND VALUE
}

\author{
*Tugba Orten TUGRUL \\ *Izmir University of Economics, Turkey
}

\begin{abstract}
Previous research demonstrates that customer experiences have significant impacts on brand perceptions, choices and other consumer behaviors. Yet, very little is known about the effects of customer experiences on brands in the context of social media. Therefore, this study examines the roles of initial purchase and social media marketing brand experiences on consumer social media marketing perceptions and brand value. Results reveal that previous experience with a brand's social media sites plays a key role in increasing consumers' favorable evaluations of the sites. However, it is shown that previous brand purchase experience has no significant effect on consumer social media marketing perceptions. Additionally, findings indicate that consumers who have previous purchase and social media experiences with a specific brand evaluate the value of the brand higher than those without such experiences.
\end{abstract}

Keywords: Customer experience; brand experience; social media marketing; brand value

\section{INTRODUCTION}

Creating positive customer experiences seems to be one of the key factors that contribute to a company's success in the contemporary business environment. Hence, experiences are retained in the minds of customers with other brand-related thoughts, feelings, images, perceptions and attitudes, and then, translated to favorable brand performances (e.g., price premiums, price elasticity, market share, expansion success) (Keller and Leh mann, 2003). Previous studies reveal that customer experiences are positively associated with brand attitude, brand choice, and brand equity (Berry, 2000; Biedenbach and Marell, 2010; Fazio and Zanna, 1978; Grace and O' Cass, 2004; Ha and Perks, 2005; Havlena and Holbrook, 1986; Sheng and Teo, 2012). Although customer experiences have already received a great deal of attention among marketing practitioners, there is a need for more academic research to better understand the role of customer experiences in the brand value creation process, specifically in a social media marketing context.

Brand activity, such as developing an online brand community, is another important dimension of the customer mindset, and thus, brand value source. In this regard, marketing activities conducted in social media platforms have the potential to influence the customer mindset with respect to a brand. Indeed, previous research proves that favorable social media marketing perceptions have positive impacts on all customer equity drivers; value equity, relationship equity, and brand equity (Kim and Ko, 2012). Yet, very little is known about the interaction between brand perceptions and customer experiences (Verhoef et al., 2009).

Therefore, this article first examines the effects of consumers' previous experiences (purchase and social media sites) with a specific brand on their perceptions of the brand's social media marketing activities. Second, this study seeks evidence for the view that initial brand experiences may influence customers' subsequent brand value evaluations.

The next section provides a brief literature review on customer experiences and social media marketing concepts, leading to the development of hypotheses. After, the research methodology is presented, along with the analysis and results. The paper concludes with a discussion of the findings and their managerial implications, as well as suggestions for future research.

\section{LITERATURE REVIEW AND HYPOTHESES Customer Experiences and Brands}

Customer experience is defined as "the internal and subjective response customers have to any direct or indirect contact with a company. Direct contact generally occurs in the course of purchase, use, and service 
and is usually initiated by the customer. Indirect contact most often involves unplanned encounters with representatives of a company's products, service or brands and takes the form of word-of-mouth recommendations or criticisms, advertising, news reports, reviews and so forth" (Meyer and Schwager 2007; 118). Therefore, a customer experience can occur at any time during the entire process of information search, decision making, purchasing, product usage and after-sale service (Ha and Persk, 2005; Verhoef et al., 2009).

Previous research illustrates the effects of customer experiences on attitudes, feelings and purchase intentions (Fazio and Zanna, 1978; Grace and O' Cass, 2004; Ha and Perks, 2005; Havlena and Holbrook, 1986). Havlena and Holbrook (1986) highlight the importance of the role of the emotional aspect of consumption experiences in understanding brand choices and other consumer behaviors. Grace and O' Cass (2004) demonstrate the significant impacts of experiences on consumers' feelings, satisfaction and brand attitudes in the context of services. Fazio and Zanna (1978) find that brand attitudes formed through direct experiences are held with greater confidence and lead to better attitude-behavior consistency compared to those derived from indirect experiences. Ha and Perks (2005) examine the impact of consumer website experiences on brands in the context of internet-based marketing. Findings show that, in particular, consumers' positive navigations and perceptions with a specific brand's website enhance familiarity with the brand, customer satisfaction and brand trust.

Brands serve as means to provide and enhance customer experiences (Schmitt, 1999). In this regard, the experience can be considered as the result of the customers' interpretations of their interactions with brands (Ghose, 2007). Several studies clearly show that customer experiences positively affect brand equity (Berry, 2000; Biedenbach and Marell, 2010; Sheng and Teo, 2012). In a B2B context, Biedenbach and Marell (2010) show that customer experience has a significant impact on the formation of all the dimensions of brand equity, namely, brand awareness, brand as sociations, perceived quality and brand loyalty. Sheng and Teo (2012) focus on the mediating role of customer experiences on the mobile brand equity, and find that perceived usefulness, entertainment, and aesthetics attributes of products enhance brand equity through customer experiences. Berry (2000) argue that brand marketing efforts and word-of-mouth communications have the highest influence on brand meaning when consumers have had little or no direct experience with a company's products or services. In contrast, customer experience is the most influential factor when consumers actually have experienced the offer. In addition, brand meaning plays a key role in cultivating brand equity for experienced customers. An understanding of the role of previous customer experiences with a brand is therefore critical to an understanding of the development of brand perceptions and value. Thus, the interaction between brands and customer experiences is an important area for future research (Verhoef et al., 2009).

Furthermore, social media boosts the co-creation of experience-based brand value. Co-creation refers to the "joint creation of value by the company and the customer", where experiences are the basis for value creation (Prahalad and Ramaswamy, 2004: 8). Many brands are now seeking to deliver perfect experiences leading customers to become advocates for the company (Frow and Payne, 2007). Customer engagements in highquality dialogues and interactions with companies create an experience environment in which the customer becomes the co-creator of the experience, and the experience itself represents the brand (Prahalad and Ramaswamy, 2004). Social media can be considered as a new venue for an experience co-creation environment. This new communication landscape enables social interaction and information exchange between consumers, consumer communities and brands. Given the fact that networked consumers are increasingly co-creating value with companies (Prahalad and Ramaswamy, 2004), social media marketing activities can be used to create positive and enjoyable customer experiences. Moreover, such experiences are important brand value chain multipliers.

\section{Social Media and Marketing}

Social Media is "a group of Internet-based applications that build on the ideological and technological foundations of Web 2.0, and that allow the creation and exchange of User Generated Content" (Kaplan and Haenlein, 2010: 61). This form of media incorporates a wide range of highly interactive platforms, such as blogs, company-sponsored discussion boards and chat rooms, consumer product or service ratings websites and forums, Internet discussion boards and forums, moblogs and social networking sites (Mangold and Faulds, 2009). Social media enables consumers to in itiate, discuss and share online information to educate 
each other about products, services and brands (Blackshaw and Nazzaro, 2004). Therefore, internet-based messages communicated through social media channels impact awareness, opinions, attitudes, information searching and decision-making behaviors, and after-sale evaluations of consumers (Mangold and Faulds, 2009). It can significantly influence a firm's reputation, sales performance, and even survival (Kietzmann et al., 2011). A social media report published by Nielsen and NM Incite (2012) provides insights into the impacts of social media on consumer behavior, and thus, brand marketing. According to the report, $60 \%$ of consumers learn more about a specific brand or retailer through social networking sites, and $63 \%$ prefer to read consumer-generated reviews online, while 3 out of 5 create their own reviews. Research also shows that consumers are more likely to trust the recommendations of their friends and family, but 2 out of 3 respondents said they were moderately influenced by advertising on social media. Moreover, $42 \%$ of 18 - to 34-year-old social media users expect customer support within 12 hours of a complaint. These findings indicate that social media is becoming increasingly important to consumers in discovering and sharing information about brands and products. Companies, on the other hand, can use this new communication channel in building, promoting and protecting brands, and engaging with target audiences at a customer service level.

As the influence of social media on consumers continues to grow, companies are increasingly integrating it into their traditional marketing activities. The Social Media Examiner report (Stelzner, 2014) demonstrates that $92 \%$ of surveyed marketers think that social media is important for their business, $97 \%$ participate in social media marketing, $56 \%$ have at least two years of social media marketing experience and among these, $65 \%$ spend at least 6 hours per week on social media activities. Increasing exposure and traffic are the major two benefits of social media marketing, cited by $80 \%$ and $92 \%$ of marketers, respectively. The use of social med ia to facilitate exchanges between consumers and companies is defined as social media marketing (Tuten and Solomon, 2013). This recently emerging concept encompasses a wide range of marketing objectives, including communication, interaction and engagement with consumers in the online platforms where they naturally spend time (Evans and McKee, 2010; Kim and Ko, 2012). Social media delivery tools have global reach capabilities and enables instantaneous, real-time and two-way communication (Kim and Ko, 2012; Mangold and Faulds, 2009). By using social media, marketers can introduce and promote products, brands, or events to consumers more directly and also at lower costs compared to traditional communication outlets (Hun, 2010). Monitoring and analyzing customer interactions with organizations and other customers enables marketers to make a range of adjustments, such as modifying products and tuning messages according to the experiences and desires of customers (Evans and McKee, 2010).

Previous studies point out the effects of the perceived social media marketing activities by consumers on brands (Erdoğmuş and Çiçek, 2012; Kim and Ko, 2012). Erdoğmuş and Çiçek (2012) found that brand loyalty is positively related to four factors; advantageous social media marketing campaigns offered by a brand, the relevancy of the content on a brand's social media platforms, the popularity of the content among friends and other users, and the variety of platforms and applications provided by a brand in social media environments. Kim and Ko (2012) discovered that social media marketing by luxury brands that entertains customers, enables interaction among users and promotes word-of-mouth enhances customer equity and purchase intention.

Given the fact that branding has also an important role to play in building and supporting customer experiences (Frow and Payne, 2007; Schmitt, 1999), marketing activities on social media platforms is expected to create favorable brand experiences. Moreover, Verhoef et al. (2009) speculate that customers' initial experiences with a brand may influence their subsequent brand perceptions. Thus, the following hypothesis is derived:

H1: Compared to those with no purchase experience with a specific brand, consumers with brand purchase experience will perceive social media marketing activities of the brand more favorably; (a) entertaining, (b) interactive, (c) trendy, (d) customized, and (e) word-of-mouth leading.

H2: Compared to those with no experiences with a specific brand's social media sites, consumers with brand social media experiences will perceive social media marketing activities of the brand more favorably; (a) entertaining, (b) interactive, (c) trendy, (d) customized, and (e) word-of-mouth leading. 
H3: Consumers with purchase experiences with a specific brand will evaluate the value of the brand higher than those without brand purchase experiences.

H4: Consumers with experiences with a specific brand's social media sites will evaluate the value of the brand higher than those without brand social media experiences.

\section{METHODOLOGY}

Data was collected through the administration of a structured questionnaire with a convenience sample of 345 undergraduate students. The sample composed of $47.2 \%$ male, and $52.8 \%$ female volunteer participants. The average age of the sample was $21.74(\mathrm{SD}=1.52)$. University students were selected because the current generation of young adults are frequent users of online social networks (Wilcox and Stephen, 2013) and also are much more likely to use these sites than adults of thirty or older (Lenhart et al., 2010).

In the first part of the questionnaire, respondents were asked about their purchase and social media experiences with a specific clothing brand. Brand purchase experience (BPE) and brand social media experiences (BSME) were measured with yes or no items. Then participants were asked to indicate how involved they were with clothing product category on a four-item product category involvement scale (PCI) (Yoo and Donthu, 2001, $\alpha=.82$ ). They also rated the value of the brand on a four-item overall brand equity scale (OBE) (Yoo and Donthu, 2001, $\alpha=.90$ ). Next, following the pioneering research in social media marketing area, participants were asked to review a visual stimulus expressing the brand's social media marketing activities on its current social media sites (Kim and Ko, 2012). Afterward, participants were asked to indicate their perceptions of the brand's social media marketing activities on the following scales: a twoitem entertain ment $(\alpha=.94)$, a three-item interaction $(\alpha=.87)$, a two-item trendiness $(\alpha=.83)$, a two-item customization $(\alpha=.86)$ and a two-item word-of-mouth $(\alpha=.70)$ scale (Kim and Ko, 2012). All items were assessed on a five-point Likert scale ranging from " 1 = strongly disagree" to " $5=$ strongly agree" .

\section{ANALYSIS AND RESULTS}

The reliability of the scales was assessed using Cronbach's alpha. As shown in Table 1, the two-item measure of trendiness did not show acceptable reliability $(\alpha=.42)$, and thus, a one-item measurement was used in the subsequent analyses: "Using this brand's social media is very trendy". All the other constructs yielded favorable results with a reliability level of 0.7 or above (Nunnally, 1994).

Table 1. Scale Item Numbers and Scale Reliability

\begin{tabular}{lll}
\hline Construct & Number of Items & Chronbach's Alpha \\
\hline Entertainment & 2 & .78 \\
Interaction & 3 & .83 \\
Trendiness & 2 & .42 \\
Customization & 2 & .76 \\
WoM & 2 & .77 \\
Product Involvement & 4 & .72 \\
Brand Equity & 4 & .83 \\
\hline
\end{tabular}

Data showed that although $82.3 \%$ of participants had purchase experiences, only $18.3 \%$ had previous experiences with the brand's social media sites. Results also demonstrated that respondents had a high level of involvement with clothing product category $\left(\mathrm{M}_{\mathrm{PCI}}=3.52, \mathrm{SD}=.73\right)$.

Results for Brand Purchase Experience Effect on Consumer Social Media Marketing Perceptions

Consumers' social media marketing perceptions was examined by five one-way ANOVAs, with brand purchase experience as the factor and product category involvement as a covariate. Hypothesis 1 asserts that consumers with purchase experiences of a specific brand are likely to perceive social media marketing activities of the brand more favorably than those without this experience. Results indicated that there is no 
significant effect of brand purchase experience on social media marketing perceptions of consumers $\left[\mathrm{F}_{\text {entertainment }}(1,341)=.999, \mathrm{p}=.318 ; \mathrm{F}_{\text {interaction }}(1,341)=.270, \mathrm{p}=.604 ; \mathrm{F}_{\text {trendiness }}(1,339)=.053, \mathrm{p}=.817\right.$; $\left.\mathrm{F}_{\text {customization }}(1,341)=2.775, \mathrm{p}=.097 ; \mathrm{F}_{\mathrm{wom}}(1,341)=.944, \mathrm{p}=.332\right]$. Therefore H1a, H1b, H1c, H1d and H1e are not supported at $\mathrm{p}<0.05$ level.

\section{Results for Brand Social Media Experience Effect on Consumer Social Media Marketing Perceptions}

Consumers' social media marketing perceptions were examined by five one-way ANOVAs, with brand social media experience as the factor, and product category involvement as a covariate. Results revealed a significant main effect of brand social media experiences of consumers on entertain ment $[\mathrm{F}(1,341)=8.504$, $\mathrm{p}=.004]$, trendiness $[\mathrm{F}(1,339)=.6 .887, \mathrm{p}=.009]$, customization $[\mathrm{F}(1,341)=5.310, \mathrm{p}=.022]$ and $\mathrm{WoM}[\mathrm{F}$ $(1,341)=22.518, \mathrm{p}<0.00$ ] dimensions of the perceived social media marketing activities, supporting H2a, $\mathrm{H} 2 \mathrm{c}, \mathrm{H} 2 \mathrm{~d}$ and H2e. Compared to those without social media marketing experiences, consumers with these experiences perceived social media marketing activities of the brand as mo re entertaining $\left(\mathrm{M}_{\text {withBSMME }}=3.59\right.$, $\left.\mathrm{SD}=.81 \mathrm{vs} . \mathrm{M}_{\text {withoutBSMME }}=3.20, \mathrm{SD}=.85\right)$, trendy $\left(\mathrm{M}_{\text {withBSMME }}=3.15, \mathrm{SD}=1 \mathrm{vs} . \mathrm{M}_{\text {withoutBSMME }}=2.80, \mathrm{SD}\right.$ $=.94)$, customized $\left(\mathrm{M}_{\text {withBSMME }}=3.44, \mathrm{SD}=.81\right.$ vs. $\left.\mathrm{M}_{\text {withoutBSMME }}=3.18, \mathrm{SD}=.79\right)$ and word-of-mouth leading $\left(\mathrm{M}_{\mathrm{withBSMME}}=3.44, \mathrm{SD}=.86 \mathrm{vs} . \mathrm{M}_{\text {withoutBSMME }}=2.83, \mathrm{SD}=.94\right)$. Ho wever, the effect of brand social media experiences on interactive dimension $(\mathrm{H} 2 \mathrm{a})$ is not supported $\left[\mathrm{M}_{\mathrm{withBSMME}}=3.44, \mathrm{SD}=.92\right.$ vs. $\mathrm{M}_{\mathrm{withoutBSMME}}=3.31, \mathrm{SD}=.82, \mathrm{~F}(1,341)=.765, \mathrm{p}=.382$ ]. Results are depicted in Figures 1-4.

Figure 1. BSME Effect on Entertainment

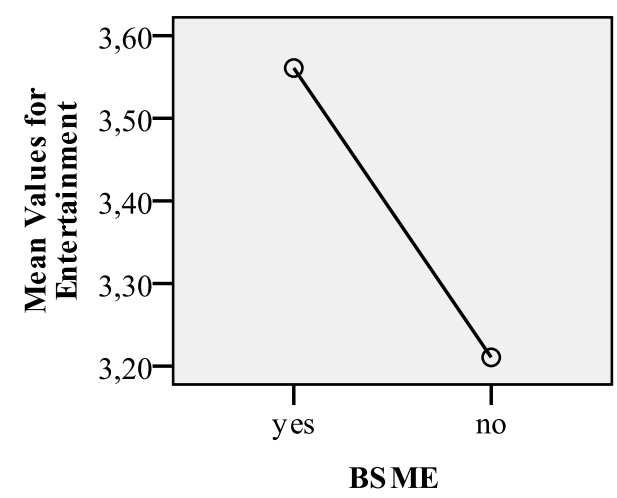

Figure 1. BSME Effect on Customization

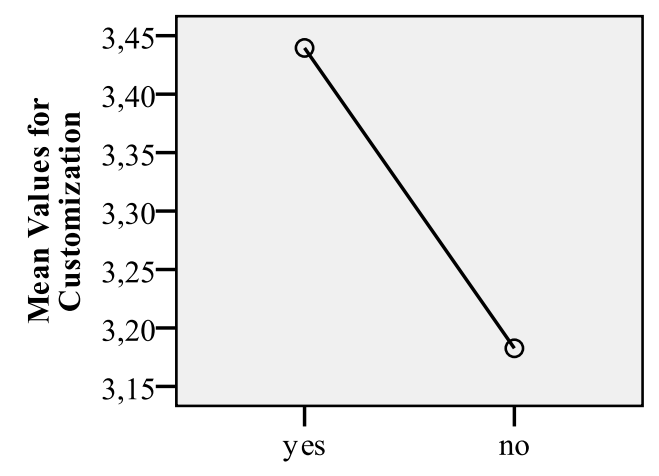

BSME
Figure 2. BSME Effect on Trendiness

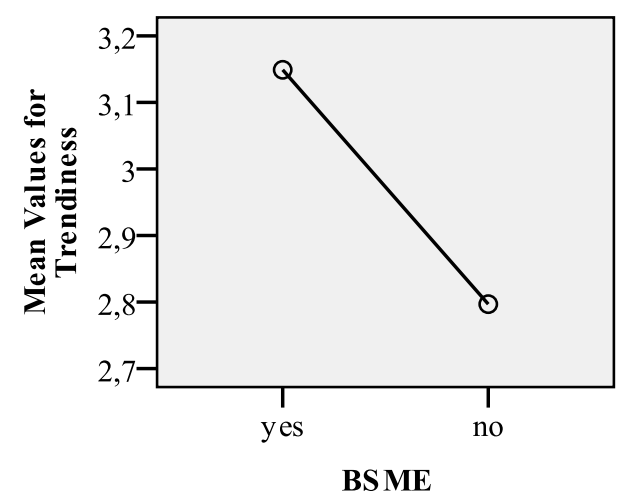

Figure 2. BSME Effect on WoM

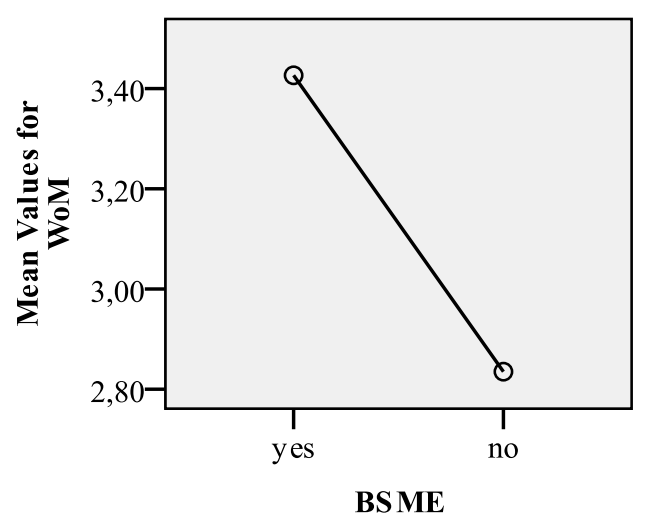




\section{Results for Brand Purchase Experience Effect on Brand Equity}

The effect of brand purchase experience on brand equity was examined by a one-way ANOVA with product category involvement as a covariate. According to Hypothesis 3, it was anticipated that consumers with purchase experiences of a specific brand are likely to evaluate the value of the brand higher than those without these experiences. The results of one-way ANOVA test demonstrated consumers with brand purchase experiences $\left(\mathrm{M}_{\mathrm{withBPE}}=2.84, \mathrm{SD}=.74\right)$ had higher brand equity evaluations than consumers without any brand purchase experiences $\left(\mathrm{M}_{\text {withoutBPE }}=2.47, \mathrm{SD}=.80\right)$ with $\mathrm{F}(1,341)=11.567, \mathrm{p}<0.00$. Thus, Hypothesis 3 is supported.

\section{Results for Brand Social Media Experience Effect on Brand Equity}

The effect of brand social media experience on brand equity was examined by a one-way ANOVA with product category involvement as a covariate. Hypothesis 4 predicts that consumers with social media experiences of a specific brand are likely to evaluate the value of the brand higher than those without these experiences. As expected, consumers with brand social media experiences tend to attach higher values to the brand $\left(\mathrm{M}_{\text {withBSME }}=3.03, \mathrm{SD}=.76\right.$ vs. $\left.\mathrm{M}_{\text {withoutBSME }}=2.72, \mathrm{SD}=.75\right)$. The results of one-way A NOVA test at $\mathrm{p}<0.05$ level showed that there was a significant difference between the consumers with and without brand social media experiences $[\mathrm{F}(1,341)=8.382, \mathrm{p}=.004]$. Results for $\mathrm{H} 3$ and $\mathrm{H} 4$ are shown in Figures 5 and 6 .

Figure 5. BPE Effect on Brand Value

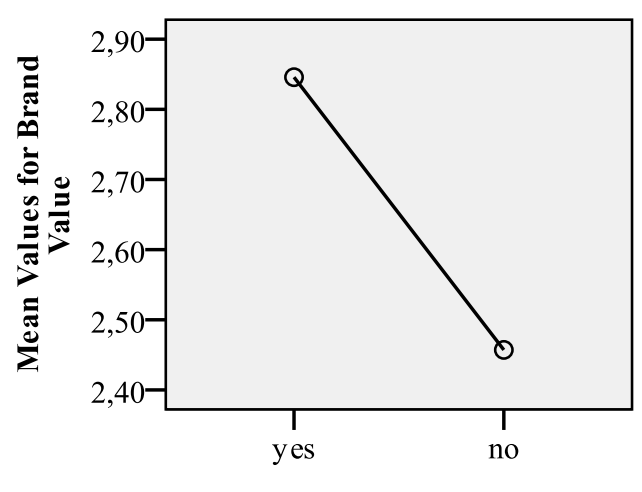

BPE
Figure 6. BSME Effect on Brand Value

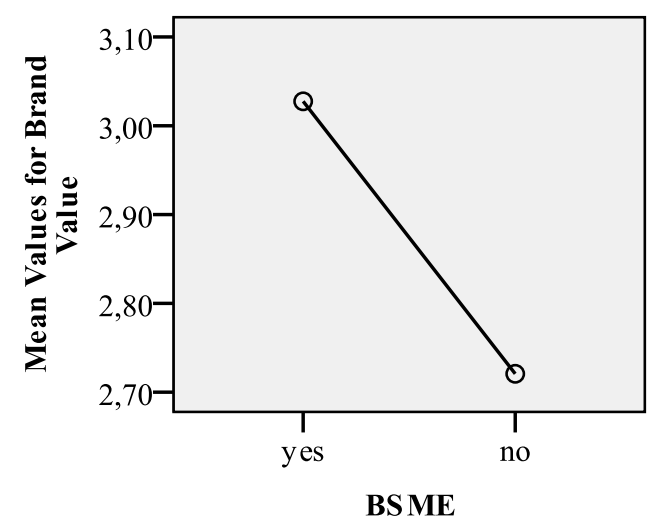

\section{CONCLUSION AND DISCUSSION}

This study examined the influences of consumers' previous purchase and social media experiences with a specific brand on the brand's perceived social media marketing activities and overall value evaluations. The effect of brand purchase experience on customers' perceptions about the social med ia marketing activities of a brand was not significant. Future research, however, should further investigate the role of purchase experiences on consumer perceptions in the social media marketing context to determine whether, for instance, the interaction between brand purchase experience and brand attitude has a significant impact on the perceived social media marketing activities of a brand by consumers. In addition, the results support the view that prior purchase experience with a brand has a substantial impact on brand value. This indicates that initial purchase experience has a substantial impact on brand-choice for subsequent purchases. The results also provide encouraging empirical support for the hypothesized effect of social media experiences on social media marketing evaluations. Experiences with a specific brand's social media sites is more likely to lead to an evaluation of the social media marketing activities as entertaining, trendy, customized and word -of-mouth leading. Additionally, the finding that social media experience is a determinant of brand value suggests that consumers with experiences with a specific brand's social media sites are likely to have a higher evaluation of the brand higher than those without. However, an important question that is yet to be answered is whether positive social media experiences influence customer perceptions and brand evaluations differently than negative social media experiences. 
The results provides companies with new evidence highlighting the importance of creating customer experiences in developing favorable social media marketing perceptions and enhancing brand value. The findings point to the need for marketing managers to pay more attention to enabling customers to experience a brand on the social media landscape. As a consequence, a company not only needs to have a social media presence, but also to develop effective social media marketing activities, and also to optimize its social media marketing efforts to create customer experiences with the potential to produce more favorable brand perceptions and enhanced brand value in the future. Moreover, regarding the role of purchase experiences, findings suggest that customers evaluate a brand's social media marketing activities independently from previous brand purchase experiences. Thus, social media can be considered as a communication tool that allows marketers to engage in a new and different approach to the brand value creation process, which can reinforce other types of positive brand perceptions. In addition, a social media strategy needs to be integrated with other communication mix elements to promote interactions with target customers, and therefore, ach ieve various marketing objectives. 


\section{REFERENCES}

Berry, L. L. (2000). Cultivating service brand equity. Journal of the Academy of Marketing Science, 28 (1), 128-137.

Biedenbach, G., \& Marell, A. (2010). The impact of customer experience on brand equity in a business-tobusiness services setting. Journal of Brand Management, 17, 446-458.

Blackshaw, P., \& Nazzaro, M. (2004). Consumer-generated media (CGM) 101: Word-of-mouth in the age of the web-fortified consumer. Retrieved from http://www.brandchannel.com/images/papers/222_cgm.pdf.

Erdoğmuş, İ. E., \& Çiçek, M. (2012). The impact of social media marketing on brand loyalty. Procedia Social and Behavioral Sciences, 58, 1353-1360.

Evans, D., \& McKee, J. (2010). Social media marketing: The next generation of business engagement . Indianapolis: Wiley.

Fazio, R. H., \& Zanna, M. P. (1978). On the predictive validity of attitudes: The roles of direct experience and confidence. Journal of Personality, 46 (2), 228 -243.

Frow, P., \& Payne, A. (2007). Special is sue papers: Towards the 'perfect' customer experience. Brand Management, 15 (2), 89-101.

Ghose, K. (2007). The Strength of the brand value chain is the strength of the brand anchor. Thought Leaders International Conference on Brand Management, Birmingham Business School, University of Birmingham. Conference Paper, 24 - 25 April.

Grace, D., \& O' Cass, A. (2004). Examining experiences and post-consumption evaluations. Journal of Services Marketing, 18 (6), 450-461.

Ha, H., \& Persk, H. (2005). Effects of consumer perceptions of brand experience on the web: Brand familiarity, satisfaction and brand trust. Journal of Consumer Behaviour, 4 (6), 438-452.

Havlena, W. J., \& Holbrook, M. B. (1986). The varieties of consumption experience: Comparing two typologies of emotion in consumer behavior. Journal of Consumer Research, 13 (3), 394-404.

Hun, L.D. (2010). Growing popularity of social media and business strategy. Retrieved from http://aeaamp.wikispaces.com/file/view/Growing+Popularity+of+Social.pdf.

Kaplan, A., \& Haenlein, M. (2010). Users of the world, unite! The challenges and opportunities of Social Media. Business Horizons, 53, 59-68.

Keller, K. L., \& Lehmann, D. R. (2003). How do brands create value?. Marketing Management, May-June, 27-31.

Kietzmann, J. H., Hermkens, K., McCarthy, I. P., \& Silvestre, B. S. (2011). Social media? Get serious! Understanding the functional building blocks of social media. Business Horizons, 54, 241-251.

Kim, A. J., \& Ko, E. (2012). Do social media marketing activities enhance customer equity? An empirical study of luxury fashion brand. Journal of Business Research, 65, 1480-1486.

Mangold W. G., \& Faulds, D. J. (2009). Social media: The new hybrid element of the promotion mix. Business Horizons, 52, 357-365.

Meyer, C., \& Schwager, A. (2007). Understanding customer experience. Harvard Business Review, February, 117-126.

Nielsen and NM Incite. (2012). State of the media: The social media report 2012. Retrieved from http://www.nielsen.com/us/en/insights/reports/2012/state-of-the-media-the-social-media-report-2012.html.

Nunnally, J. C., \& Bernstein I.bH. (1994). Psychometric theory. New York: McGraw-Hill.

Prahalad, C. K., \& Ramaswamy, V. (2004). Co-creation experiences: the next practice in value creation. Journal of Interactive Marketing, 18 (3), 5-14. 
Schmitt, B. (1999). Experiential marketing. Joumal of Marketing Management,15,53-67.

Sheng, M., L., \& Teo, S., H. (2012). Product attributes and brand equity in the mobile domain: The mediating role of customer experience. International Journal of Information Management, 32, 139- 146.

Stelzner, M. A. (2014). 2014 Social media marketing industry report: How marketers are using social media to grow their businesses. Retrieved from http://www.socialmediaexa miner.co m/SocialMediaMarketingIndustryReport2014.pdf.

Tuten, T. L., \& Solomon, M. R. (2013). Social media marketing. New Jersey: Pearson Education Inc.

Yoo, B., \& Donthu, N. (2001). Developing and validating a multidimensional consumer-based brand equity scale. Journal of Business Research, 52, 1-14.

Verhoef, P. C., Lemon K. A., Parasuraman A., Roggeveen A, Tsiros M., \& Schlesinger L. A. (2009).

Customer experience creation: Determinants, dynamics and management strategies. Journal of Retailing, 85, $31-41$. 